\title{
Interpersonal violence in three Caribbean countries: Barbados, Jamaica, and Trinidad and Tobago
}

\author{
Elsie Le Franc, ${ }^{1}$ Maureen Samms-Vaughan, ${ }^{2}$ \\ lan Hambleton, ${ }^{3}$ Kristin Fox, ${ }^{4}$ and Dennis Brown ${ }^{5}$
}

Suggested citation Le Franc E, Samms-Vaughan M, Hambleton I, Fox K, Brown D. Interpersonal violence in three Caribbean countries: Barbados, Jamaica, and Trinidad and Tobago. Rev Panam Salud Publica. 2008;24(6): $409-21$.

ABSTRACT Objectives. This article reports the prevalence of two types of interpersonal violence (IPV) (sexual and physical) and one type of aggression (psychological) in three low-to-middle-income Caribbean countries. It examines IPV among adolescents and young adults as both victims and perpetrators.

Method. This population-based study compares the experiences of 15-30 year olds in countries at different levels of socioeconomic development. The Revised Conflict Tactics Scales (CTS2) and other behavioral instruments were used to assess the level and characteristics of IPV.

Results. Out of 3401 respondents, 70.9\% reported victimization by some form of violence, which was most commonly perpetrated by a relationship partner (62.8\%). Sexual violence victimization was reported more commonly by women, and was highest in Jamaica. Significant between-country differences in overall levels of reported physical violence, and psychological aggression, were evident when stratifying by perpetrator type.

Conclusions. The very high levels of reported IPV indicate very high levels of tolerance among victims, and suggest a culture of violence and of adversarial intimate relationships may be well entrenched. The findings support the view that co-occurrence of general interpersonal violence and partner violence may be limited, and that one may not necessarily be a predictor of the other. They also reveal that, among partners, not only are there no gender differentials in victimization by physical violence, but more women than men are self-reporting as perpetrators of this type of IPV.

Key words Sexual violence, domestic violence, aggression, adolescent, adult, Barbados, Jamaica, Trinidad and Tobago.

Professor Emeritus, Sir Arthur Lewis Institute of Social and Economic Studies (SALISES), The University of the West Indies, Kingston, Jamaica. Send correspondence and reprint requests to: Elsie Le Franc, Professor Emeritus, SALISES, The University of the West Indies, Mona, Kingston 7, Jamaica, West Indies; telephone: (876) 927-1234; fax: (876) 927-2409; e-mail: erlefranc@yahoo.co.uk

2 Professor of Child Health, Development and Behaviour, Section of Child Health, Department of
Obstetrics, Gynaecology \& Child Health, The University of the West Indies, Kingston, Jamaica.

3 Senior Lecturer in Biostatistics, Chronic Disease Research Centre, Tropical Medical Research Institute, The University of the West Indies, Bridgetown, Barbados.

4 Senior Research Fellow, SALISES, The University of the West Indies, Kingston, Jamaica.

5 Senior Lecturer, Department of Sociology and Social Work, The University of the West Indies, St. Augustine, Trinidad and Tobago.
Based on recent studies of violence and injury reporting high and rising rates of morbidity and mortality as well as high associated economic costs, violence and injury must now be seen as a major public health problem (1-3), especially in the Caribbean (4-6). In addition, there is growing evidence 
that the consequences of violence go far beyond immediate morbidity and mortality, comprising longer-term and negative effects on mental and reproductive health as well as general socioeconomic development (1, 7-9).

Understanding the full burden of violent behavior in a specific country requires consideration of not only mortality statistics but also morbidity statistics, which are often much higher. In the United States, for example, the estimated ratio of mortality to morbidity ranges from 1:19 to $1: 200(8,10-12)$. Although reliable morbidity data are not available for the Caribbean region, one study estimates a mortality-tomorbidity ratio range of 1:8 to 1:26 (4). In Jamaica, most admissions to casualty departments and accident and emergency units are related to injury caused by violence, with one-half of admissions resulting from intentional violence on individuals under 30 years of age (13). In Barbados and Trinidad and Tobago, injuries account for 10$25 \%$ of hospital admissions (14). In St. Vincent and the Grenadines, there were 17 murders recorded per 100000 , versus 1257 and 863 per 100000 for assault and wounding, respectively (15).

Increasing awareness of domestic violence has led to a recent increase in related literature, which reports incidence rates ranging from 16 to $69 \%$ (1, 16-17). In the Caribbean, there is limited quantitative data on the subject but considerable qualitative evidence that the problem is serious, growing, and widespread (4, 18-21). A clearer understanding of the characteristics, prevalence, and causes of interpersonal violence (IPV) and aggression has therefore become critical.

Violence, violent injury, and other health-risky behaviors often begin at a very early age. As in most countries in the Americas $(5,10,22)$, violence and injury is now the leading cause of death among adolescents and young adults in the English-speaking Caribbean, with injury as the leading cause of death among 5-14 year-old males, and homicide and suicide the most important causes of death among the 15-24 year age group (4). Partner violence exists among adolescents and young adults (23). In Jamaica, qualitative data suggest that the adolescent partnering process is closely linked to IPV and aggression (24).

Over time, there have been many attempts to explain antisocial behaviors, such as crimes against individuals. Yet, understanding of the magnitude and causes of this type of violence is still inadequate. With respect to the specific problem of domestic violence (including partner violence), there is still no clear consensus or overarching theoretical model to explain the causes of this phenomenon across time and/or space. There is, however, continuing debate about what should be incorporated in the definition of various types of violence, and their respective causes. Given the wide variations of violence in terms of its expressions, rationalizations, and locations, these causes are likely to be complex and multiple (1, 25-30).

There are also conflicting views regarding the role of gender in IPV and aggression. Certainly, the feminist movement has been critical in raising awareness of the serious problem of female battery and spurring its incorporation into national health agendas. However, there is increasing recognition of the reality of male victimization and the fact that the "gender gap" (a disproportionate number of female victims versus male victims) may not exist or is narrowing $(25,30-33)$. It is therefore important that analyses of IPV and aggression be gender-differentiated to determine possible differences in incidence rates.

Although current evidence indicates low- and middle-income countries have a disproportionately high rate of IPV and aggression (1), research on the determinants of this type of violence in these countries remains limited (34-38). Most existing explanatory models and frameworks were developed in high-income North Atlantic countries. Therefore, their usefulness in low- to middle-income countries needs to be explored, particularly in the Caribbean, where the economic situation, as well as sociocultural mores and practices, may be quite different. Relevant studies conducted in the Ca- ribbean include research on the problem of IPV and aggression in schools and its effect on educational performance and nutrition (34, 38-40); the impact of exposure to violence-related psychological distress (37); and the role of protective factors against violence, such as family connectedness (38).

This article provides an initial report of a population-based survey of IPV and aggression among adolescents and young adults (15-30 years of age) in three Caribbean countries (Barbados, Jamaica, and Trinidad and Tobago). It includes the reported prevalence of two types of IPV (sexual and physical) and one type of aggression (psychological) experienced by victims, as well as perpetrators. This is the first quantitative, comparative, $\mathrm{Ca}$ ribbean study utilizing the Revised Conflict Tactics Scales (CTS2) and other behavioral instruments to assess the extent and characteristics of IPV and aggression in the region, and collecting information on a range of possible determinants, including education and occupation; family structure and migration patterns; household composition; social support networks; parenting; and psychosocial variables such as perceptions of self-esteem, exclusion, and personal power. The study aims to determine the magnitude of physical and sexual IPV, and psychological aggression, ${ }^{6}$ as well as the possible role of gender in victimization or perpetration by/of these types of violence. It also investigates differences between violence among partners and violence among acquaintances and strangers.

\section{MATERIALS AND METHODS}

\section{Study design}

All individuals aged 15-30 years were eligible for participation in this study. Actual study participants were

\footnotetext{
Although some data are provided on psychological aggression to illustrate the likely magnitude of the problem compared to experiences with actual violence, the focus of the study is sexual and physical violence.
} 
selected using a three-level clustersampling regime (participants within households within communities) based on the standard methodology used by the national statistical office of each participating country. A community was defined as a contiguous group of census enumeration districts (EDs) containing at least 80 households. Communities were stratified using an urban/rural classification. Those that allowed for the best capture of the full range of prevalent socioeconomic conditions, based on standard measures (household density, measured as the number of people in the household divided by the number of bedrooms; number of household possessions; and unemployment rate), were selected for study. Within the selected communities, the EDs with probability proportional to size (PPS) were chosen. Within each selected ED, a random selection of households was visited based on a planned route (with a randomly chosen starting point). One eligible participant from each household was chosen as a representative. If a household contained more than one eligible individual, the study participant was chosen using random selection tables. Study participant selection was then stratified by sex and age to ensure adequate representation of both men and women of all ages.

\section{Sample size}

Based on anecdotal reports about violence in the three countries of study, a level of IPV and aggression of between $30 \%$ and $50 \%$ was expected. The use of logistic regression to analyze the effect of a single covariate (adjusted for prior covariates) required a sample of at least 409 study participants in each country and resulted in an odds ratio (OR) of 1.75 (IPV/aggression-positive individuals versus IPV/aggression-negative individuals) for $90 \%$ statistical power and a test significance of $5 \%$ (at an IPV prevalence of $30 \%$ ). This sample size was inflated to account for a survey design effect of 2 and a non-response rate of $20 \%$, providing a final sample size in each country of 982 study participants.

\section{Statistical methods}

The proportion of study participants (survey respondents) that experienced IPV victimization from strangers or acquaintances was calculated and stratified by country, sex, and type of violence (physical versus sexual). The prevalence of aggression within relationships was calculated using a third category (psychological aggression), with the survey respondent as either victim or perpetrator. Logistic regression models were used to examine the effect of age, sex, and country differences on both IPV and aggression prevalence. All prevalence estimates and regression models were weighted to account for the survey design and levels of non-response. Stata statistical software (Version 10, StataCorp LP, College Station, Texas, USA) was used for all analyses. Although statistical significance was assumed at $p \leq 0.05$, all confidence intervals (CIs) and $p$ values are presented, where appropriate, to clarify the exact strength of statistical relationships.

\section{Measures}

This study's definition of physical violence is based on the following World Health Organization (WHO) definition of violence: "the intentional use of physical force or power, threatened or actual, against ... another person, or against a group or community, ... that either results in or has a high likelihood of resulting in injury, death, psychological harm, maldevelopment or deprivation ..." (1: 5). The term "interpersonal violence," in this study, refers to violence between family members and intimate partners as well as violence between acquaintances and strangers. Within this IPV category, this study differentiates violence between partners (i.e., within intimate relationships) from violence between persons known to each other (including relativessome of whom could be members of the domestic household) and violence between strangers. Reflecting the realities in the Caribbean and other countries, where relationship partners and nuclear family members do not necessarily co-reside-and in contrast to most literature on the subject, which may use the terms "domestic violence" and "partner violence" interchangeably-this study focuses on the personal or relationship context of the violence perpetrated or experienced, as opposed to its venue (and therefore does not use the term "domestic violence").

Violence perpetrated by partners. Partner violence was assessed using the Revised Conflict Tactics Scales (CTS2) $(41,42)$ previously validated in Jamaica. The CTS2, which yields subscale reliability scores ranging from 0.72 to 0.81 (Cronbach's alpha), includes two questions each for 39 different items, resulting in a total of 78 questions comprising five different scales measuring experiences with violence as both victim and perpetrator. These five scales include negotiation, psychological aggression, physical assault, injury, and sexual coercion. In this study, the CTS2 was used to assess the history of involvement in partner IPV as well as different experiences with violence-both minor and severe. Although the study questions focused on the 12 months preceding the survey, reports of incidents occurring prior to that time period were also recorded. Therefore, the data reported in this article refer to incidents "ever experienced." Incidents were classified by type and severity of violence and by role of respondent (perpetrator, victim, or both).

Violence perpetrated by acquaintances and strangers. Respondents were asked about sexual and physical violence perpetrated against them by strangers as well as persons known to them (not including intimate partners). The questions were developed using the methodology implemented in the Violence Against Women Survey (VAWS) conducted in Canada in 1993 (43) and were tested and validated at the national level in Barbados. This methodology, which allows for analysis of IPV regardless of the gender of the victim or perpetrator, has 
also been previously used successfully in the Caribbean $(22,44)$.

Drawing on the two instruments mentioned above, sexual violence (or coercion) was defined as something that occurred when any individual forced or attempted to force the respondent into any sexual activity $\mathrm{s} /$ he did not want by threatening, holding down, or hurting the respondent in some way.

Socioeconomic status. While most countries rely on consumption-based measurements to assess socioeconomic status, the use of this type of measure has proven challenging in the
Caribbean region. Therefore, in this study, education and occupational status (employment versus unemployment) were used as proxies for socioeconomic status. Educational levels were measured by combining two classifying criteria: years of schooling, and type of school last attended (primary, secondary, and tertiary).

\section{Response rates}

Survey response rates are presented in Table 1. There were a total of 3401 completed questionnaires. More were collected in Jamaica ( $41 \%$ of all completed surveys) than in Barbados or Trinidad and Tobago (29\% each in both countries).

\section{RESULTS}

\section{Country profiles}

Table 2 provides sociodemographic data on the three countries studied, illustrating important differences in terms of gross domestic product (GDP) per capita, GDP annual growth rate, level of urbanization, and migra-

TABLE 1. Number of individuals approached, number of questionnaires completed, and rate of response, by country, for survey conducted in Barbados, Jamaica, and Trinidad and Tobago, 2003-2004

\begin{tabular}{lccc}
\hline & \multicolumn{2}{c}{ Number of respondents } & \\
\cline { 2 - 3 } \multicolumn{1}{c}{ Country } & $\begin{array}{c}\text { Individuals } \\
\text { approached }\end{array}$ & $\begin{array}{c}\text { Completed } \\
\text { questionnaires }\end{array}$ & $\begin{array}{c}\text { Rate of response } \\
(\%)\end{array}$ \\
\hline Barbados & 1285 & 1003 & 78.1 \\
Jamaica & 1578 & 1402 & 88.8 \\
Trinidad and Tobago & 1296 & 996 & 76.9 \\
$\quad$ Total & 4159 & 3401 & 81.3 \\
\hline
\end{tabular}

TABLE 2. Sociodemographic data on survey study sites (Barbados, Jamaica, and Trinidad and Tobago) ${ }^{\mathrm{a}}$

\begin{tabular}{|c|c|c|c|c|}
\hline Country & Barbados & Jamaica & $\begin{array}{l}\text { Trinidad } \\
\text { and } \\
\text { Tobago }\end{array}$ & $\begin{array}{l}\text { Latin America } \\
\text { and the } \\
\text { Caribbean }\end{array}$ \\
\hline GDP per capita (PPPb in US\$) (2004) & 15720 & 4163 & 12182 & 7.964 \\
\hline Human Development Index score $(2007)^{c}$ & 0.892 & 0.736 & 0.814 & 0.795 \\
\hline World ranking (177 countries) & 31 & 101 & 59 & $N A^{d}$ \\
\hline Developing country ranking (108 countries) & 1 & 34 & 12 & NA \\
\hline GDP per capita annual growth rate $(1990-2000)(\%)$ & 1.7 & -0.4 & 2.3 & NA \\
\hline Migratory balance ${ }^{\mathrm{e}}$ & -250 & -21700 & -3800 & -378743 \\
\hline Level of urbanization (\%) & 51.2 & 57.1 & 74.9 & 76.6 \\
\hline Annual urban growth rate (1996-2002) (\%) & 1.47 & 1.71 & 1.07 & 2.04 \\
\hline \multicolumn{5}{|l|}{ Union type $(\%)^{\dagger}$} \\
\hline Married & $30^{\mathrm{g}}$ & 16 & 70 & $\mathrm{r}^{\mathrm{h}}$ \\
\hline Common-law cohabitation & 20 & 24 & 27 & $\ldots$ \\
\hline Visiting & 2 & 36 & 3 & $\ldots$ \\
\hline
\end{tabular}

Sources: 1998 Reproductive Health Survey, Jamaica; Central Statistical Office, Trinidad and Tobago; Barbados Census, 2000; and UNDP Human Development Report 2007.

a Most recent data.

${ }^{b}$ PPP $=$ purchasing power parity.

${ }^{c}$ Annual rating of national well-being (on an ascending scale of $0-1$ ), based on life expectancy, literacy, education, and GDP, by the United Nations Development Programme (UNDP).

d NA = not applicable.

e Difference between arrivals and departures of country inhabitants.

${ }^{\dagger}$ Percentages may not add up to $100 \%$ as some respondents have never been or are no longer in a union.

9 This figure refers to mothers aged 15-49 at age of first child.

h No observations made. 
TABLE 3. Selected characteristics of survey respondents, by country, in Barbados, Jamaica, and Trinidad and Tobago, 2003-2004

\begin{tabular}{|c|c|c|c|c|c|}
\hline Characteristic & $\begin{array}{c}\text { Barbados } \\
n^{\mathrm{a}}=1003\end{array}$ & $\begin{array}{c}\text { Jamaica } \\
n=1402\end{array}$ & $\begin{array}{c}\text { Trinidad and } \\
\text { Tobago } \\
n=996\end{array}$ & $\begin{array}{l}\text { All three } \\
\text { countries } \\
n=3401\end{array}$ & $P^{\mathrm{b}}$ \\
\hline Age (mean-SD $\left.{ }^{c}\right)$ & $21.1(4.2)$ & $20.7(4.4)$ & $21.1(4.3)$ & $21.0(4.3)$ & 0.01 \\
\hline Age group (years) (\%) & & & & & 0.01 \\
\hline $15-18$ & 33.7 & 39.8 & 33.7 & 36.2 & \\
\hline 19-22 & 30.1 & 25.5 & 26.8 & 27.2 & \\
\hline $23-26$ & 21.4 & 20.7 & 24.3 & 21.9 & \\
\hline $27-30$ & 14.8 & 14.1 & 15.2 & 14.6 & \\
\hline Sex (\% female) & 48.4 & 60.1 & 48.9 & 53.3 & $<0.001$ \\
\hline Ethnicity (\%) & & & & & $<0.001$ \\
\hline Black & 90.4 & 90.6 & 39.3 & 72.0 & \\
\hline East Indian & 0.4 & 0.7 & 36.1 & 13.4 & \\
\hline Mixed (black/white) & 4.4 & 2.0 & 1.6 & 2.7 & \\
\hline Mixed (black/East Indian) & 2.0 & 4.9 & 10.9 & 6.1 & \\
\hline Other mixed & 1.3 & 0.7 & 10.5 & 4.4 & \\
\hline Other & 1.6 & 1.1 & 1.7 & 1.4 & \\
\hline Educational attainment (\%) & & & & & $<0.001$ \\
\hline Incomplete primary & 2.9 & 1.7 & 2.2 & 2.3 & \\
\hline Complete primary & 4.3 & 14.5 & 10.5 & 9.7 & \\
\hline Incomplete secondary & 7.1 & 25.5 & 20.7 & 17.8 & \\
\hline Complete secondary & 41.0 & 39.2 & 49.8 & 44.0 & \\
\hline Tertiary & 44.8 & 19.1 & 16.8 & 26.2 & \\
\hline \multicolumn{6}{|l|}{ Unemployment (\%) } \\
\hline Women & 23.8 & 30.4 & 17.1 & 23.4 & $<0.001$ \\
\hline Men & 18.4 & 19.0 & 8.4 & 15.0 & $<0.001$ \\
\hline Relationship length (years) (\%) & & & & & $<0.001$ \\
\hline$<1$ & 13.8 & 22.7 & 46.3 & 31.3 & \\
\hline $1-2$ & 54.9 & 54.8 & 40.2 & 48.0 & \\
\hline $3-4$ & 18.5 & 15.1 & 10.1 & 13.7 & \\
\hline$\geq 5$ & 12.7 & 7.4 & 3.4 & 7.0 & \\
\hline
\end{tabular}

tion. The United Nations Development Programme (UNDP) Human Development Index (HDI), a standard tool for measuring and comparing well-being across countries based on life expectancy, literacy, education, and GDP, is used to summarize the development differences between the three countries in this study. Jamaica ranks the lowest in terms of GDP per capita, while Barbados has the highest HDI rating (0.892 on an ascending scale of 0 to 1 ).

Table 3 provides selected sociodemographic characteristics of the final 3401 study participants (survey respondents). The distributions for age, sex, ethnicity, educational level, and unemployment were similar to those in the available aggregate na- tional data $(13,45-47)$. Barbados and Jamaica report roughly equivalent ethnic distributions. The Trinidad and Tobago survey respondents were divided equally between East Indian ethnicity and those of African descent. After adjusting for the confounding effect of age, women were more likely to have a higher level of education than men (OR, 1.42; 95\% CI, 1.22-1.65; $p<$ 0.001). Respondents from Barbados were more likely to have a higher level of education than either Jamaica (OR, 3.94; 95\% CI, 2.75-5.63; $p<0.001$ ) or Trinidad and Tobago (OR, 3.28; 95\% CI, 2.51-4.28; $p<0.001$ ). Unemployment was significantly higher among women, who had a 1.77 OR of being unemployed versus men (95\% CI, 1.462.14). Unemployment was lowest in
Trinidad and Tobago and was significantly higher in both Barbados $(p<$ $0.001)$ and Jamaica $(p<0.001)$.

\section{IPV among strangers, acquaintances, and partners}

Victimization. Table 4 shows the percentage of reported physical violence and sexual coercion against all survey respondents (i.e., as victims), stratified by country of participation, sex of respondent, and type of perpetrator (stranger, acquaintance, or relationship partner).

Approximately three-quarters of all respondents (ranging from 63.1 to $72.5 \%$ for men, and from 65.1 to $83.1 \%$ for women) reported being a victim of 
TABLE 4. The proportion of survey respondents reporting physical violence and sexual coercion by strangers, acquaintances, and partners, stratified by country and sex of victim, in Barbados, Jamaica, and Trinidad and Tobago, 2003-2004

\begin{tabular}{|c|c|c|c|c|c|c|c|c|c|}
\hline & Women & Men & Women & Men & Women & Men & $\begin{array}{c}\text { Age } \\
\text { difference } \\
(P)^{\mathrm{a}}\end{array}$ & $\begin{array}{c}\text { Gender } \\
\text { difference } \\
(P)^{\mathrm{a}}\end{array}$ & $\begin{array}{l}\text { Country } \\
\text { difference } \\
\qquad(P)^{\mathrm{a}}\end{array}$ \\
\hline By strangers & 6.3 & 13.4 & 11.3 & 19.8 & 6.8 & 15.3 & 0.002 & $<0.001$ & 0.01 \\
\hline By acquaintance & 9.8 & 10.7 & 17.5 & 13.1 & 9.9 & 14.8 & 0.02 & 0.55 & 0.01 \\
\hline In relationships & 50.0 & 44.7 & 45.3 & 40.4 & 45.2 & 47.7 & $<0.001$ & 0.19 & 0.13 \\
\hline In relationships & 52.8 & 39.6 & 72.6 & 57.2 & 51.6 & 52.5 & $<0.001$ & $<0.001$ & $<0.001$ \\
\hline Any physical violence & 57.3 & 55.9 & 58.3 & 54.0 & 52.5 & 61.4 & $<0.001$ & 0.43 & 0.94 \\
\hline Any sexual coercion & 57.2 & 40.2 & 76.0 & 58.4 & 53.5 & 53.5 & $<0.001$ & $<0.001$ & $<0.001$ \\
\hline Any violence & 72.1 & 63.1 & 83.1 & 72.5 & 65.1 & 71.2 & 0.03 & 0.01 & $<0.001$ \\
\hline
\end{tabular}

a Differences in the prevalence of each type of IPV/aggression were assessed using logistic regression adjusting for age (in 4-year age groups), gender, and country (Barbados, Jamaica, and Trinidad and Tobago) of survey respondent, simultaneously, with statistical significance assumed at $p \leq 0.05$.

TABLE 5. Effect of age, gender, and country of survey respondent on physical violence and sexual coercion on respondents by strangers or acquaintances, in Barbados, Jamaica, and Trinidad and Tobago, 2003-2004

\begin{tabular}{|c|c|c|c|c|c|c|}
\hline & \multicolumn{3}{|c|}{ Physical violence } & \multicolumn{3}{|c|}{ Sexual coercion } \\
\hline & \multicolumn{2}{|c|}{$\mathrm{OR}^{\mathrm{a}}\left(95 \% \mathrm{Cl}^{\mathrm{b}}\right)$} & \multirow[t]{2}{*}{$P^{c}$} & \multicolumn{2}{|c|}{ OR $(95 \% \mathrm{Cl})$} & \multirow[t]{2}{*}{$P^{c}$} \\
\hline Age (versus $15-18$ age & & & & & & \\
\hline $19-22$ & 1.45 & $(1.16-1.81)$ & $<0.001$ & 1.67 & $(1.19-2.35)$ & 0.003 \\
\hline $23-26$ & 1.56 & $(1.24-1.96)$ & $<0.001$ & 1.69 & (1.19-2.39) & 0.004 \\
\hline $27-30$ & 1.59 & $(1.21-2.07)$ & $<0.001$ & 1.45 & $(0.95-2.23)$ & 0.09 \\
\hline \multicolumn{7}{|l|}{ Country (versus Barbados) } \\
\hline Jamaica & 1.68 & $(1.29-2.20)$ & $<0.001$ & 2.06 & $(1.33-3.19)$ & $<0.001$ \\
\hline Trinidad and Tobago & 1.12 & $(0.86-1.47)$ & 0.40 & 0.87 & $(0.51-1.49)$ & 0.62 \\
\hline \multicolumn{7}{|l|}{ Gender (versus men) } \\
\hline Women & 0.66 & $(0.55-0.78)$ & $<0.001$ & 4.01 & $(2.69-5.98)$ & $<0.001$ \\
\hline
\end{tabular}

some form of violence, with the violent act most commonly perpetrated by a partner within a relationship (59.0\% on male victims and $66.7 \%$ on female victims). Among women, Jamaica reported the highest level of any form of violence; among males, Barbados reported the lowest levels of any kind of violence. There was no statistically significant difference by gender $(p=0.43)$ or by country $(p=0.94)$ in the prevalence of physical violence.

The levels of any violence decreased as the victim's ages increased-falling from $72.4 \%$ among the $15-18$ year olds to $67.3 \%$ among the 27-30 year olds ( $p=0.03$ ). Reported physical violence fell from $66.2 \%$ among the 15-18 year olds to $49.0 \%$ among the 27-30 year olds $(p<0.001)$. Reported sexual coercion fell from $60.3 \%$ among the $15-18$ year olds to $50.1 \%$ among the 27-30 year olds $(p<0.001)$.

Women were more likely to be a victim of sexual coercion (OR, 1.60; 95\% CI, 1.35-1.90; $p<0.001)$. Compared to Barbados, Trinidad and Tobago had similar levels of sexual coercion ( $p=$ 0.07 , whereas Jamaica had significantly higher levels of sexual coercion (OR, 2.19; 95\% CI, 1.70-2.84; $p<0.001$ ). After adjusting for age differences, more women were victims of any violence $(\mathrm{OR}, 1.23 ; 95 \% \mathrm{CI}, 1.04-1.44 ; p=$
0.01). Compared to Barbados, Trinidad and Tobago had similar levels of overall violence, whereas Jamaica, due to increased levels of coercion, had higher levels (OR, 1.68; 95\% CI, 1.30-2.17; $p<0.001$ ).

When incidence of IPV is further disaggregated to show victimization by strangers and acquaintances (Table 5) versus victimization by relationship partners (Table 6), some differences appear. Among strangers and acquaintances, physical violence increased with age $(p<0.001)$ and was higher in Jamaica than in Barbados ( $p<0.001)$; for Trinidad and Tobago, there was no significant difference $(p=$ 
TABLE 6. The proportion of survey respondents reporting physical violence, sexual coercion, and psychological aggression within intimate relationships, in Barbados, Jamaica, and Trinidad and Tobago, 2003-2004

\begin{tabular}{|c|c|c|c|c|c|c|c|c|c|}
\hline & Women & Men & Women & Men & Women & Men & $\begin{array}{c}\text { Age } \\
\text { difference } \\
(P)^{\mathrm{a}}\end{array}$ & $\begin{array}{c}\text { Gender } \\
\text { difference } \\
(P)^{\mathrm{a}}\end{array}$ & $\begin{array}{l}\text { Country } \\
\text { difference } \\
(P)^{\mathrm{a}}\end{array}$ \\
\hline \multicolumn{10}{|l|}{ Survey respondent as victim } \\
\hline Psychological aggression & 70.7 & 76.1 & 69.4 & 66.5 & 69.3 & 66.6 & 0.16 & 0.97 & 0.07 \\
\hline Physical violence & 50.0 & 44.7 & 45.3 & 40.4 & 45.2 & 47.7 & $<0.001$ & 0.19 & 0.13 \\
\hline Sexual coercion & 52.8 & 39.6 & 72.6 & 57.2 & 51.6 & 52.5 & $<0.001$ & $<0.001$ & $<0.001$ \\
\hline Sexual coercion & 47.4 & 42.1 & 67.9 & 60.0 & 49.9 & 52.9 & $<0.001$ & 0.10 & $<0.001$ \\
\hline
\end{tabular}

0.40). Women reported less physical violence against them than did the men (OR, 0.66; 95\% CI, 0.55-0.78; $p<$ 0.001). There was a significant gender difference only for the physical violence perpetrated by strangers. Sexual coercion increased with age $(p=0.01)$ until the mid-20s age group, but appeared to fall off thereafter. Sexual coercion was more than 2 times higher in Jamaica than in either Barbados or Trinidad and Tobago $(p<0.001)$. Women were 4 times more likely to be victims of sexual coercion than men (OR, 4.01; 95\% CI, 2.69-5.98; $p<0.001)$.

\section{IPV and psychological aggression among partners only}

Table 6 shows the prevalence of reported physical and sexual IPV, and psychological aggression, within relationships (victimization as well as perpetration), stratified by country and sex of the respondent.

Victimization. Levels of psychological aggression were high. Over twothirds of all survey respondents reported a history of psychologically aggressive behavior in a past or current relationship (more than $70 \%$ in both men and women in Barbados), with no statistically significant differences according to gender $(p=0.97)$, between the three participating countries $(p=0.07)$, or across different age groups $(p=0.16)$.

\section{FIGURE 1. Physical violence and sexual coercion on survey respondents by a partner in Barbados, Jamaica, and Trinidad and Tobago, 2003-2004}

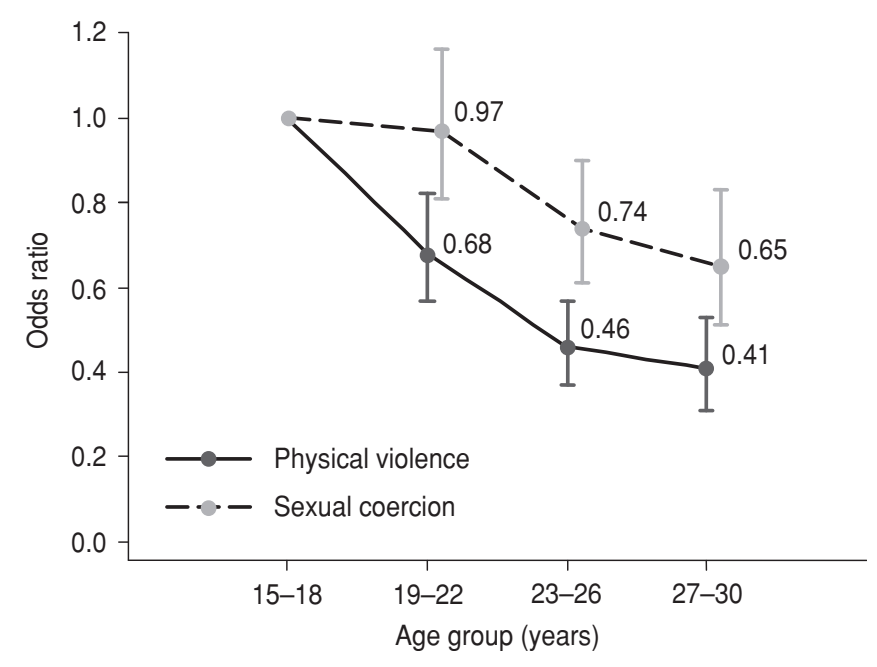

Levels of physical violence experienced among partners fell with age. When compared to the 15-18 year age group, ORs show that persons aged 19-22 years were 0.68 times less likely to be victims of violence $(95 \% \mathrm{CI}$, $0.57-0.82 ; p<0.001)$; those aged $23-26$ years were 0.46 times less likely (95\% CI, $0.37-0.57 ; p<0.001)$, and those aged 27-30 years were 0.41 less likely (95\% CI, 0.31-0.53; $p<0.001$ ) (Figure 1). However, there were no differences between the genders in the prevalence of physical violence or between the three participating countries. Figure 1 presents physical violence and sexual coercion on survey respondents, whereas
Figure 2 presents physical violence and sexual coercion by survey respondents. The age-related decline is similar in both graphs.

Sexual coercion was the only victimization experience that varied by country and by gender. Overall, the prevalence of sexual coercion reported by men was lower than that reported by women (OR, 0.69; 95\% CI, 0.58-0.82; $p<0.001)$. As with physical violence, this prevalence also fell with agebeing highest among persons 19-22 years and lowest among persons 27 years and over (Figure 1). Compared to Barbados, there was a higher prevalence of sexual coercion in Jamaica 
FIGURE 2. Physical violence and sexual coercion by survey respondents on a partner in Barbados, Jamaica, and Trinidad and Tobago, 2003-2004

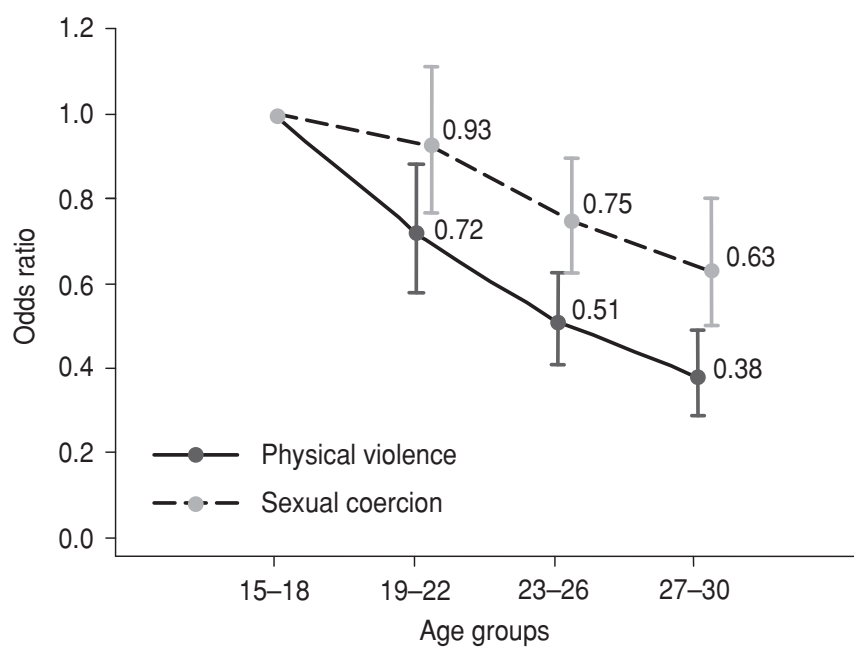

(OR, 2.18; 95\% CI, 1.67-2.85; $p<0.001)$ and in Trinidad and Tobago (OR, 1.27; 95\% CI, 1.02-1.58; $p=0.03$ ).

Perpetration. Similar to the survey reports of high levels of psychological aggression as victims, the levels of psychological aggression were high for perpetrators, with no strong statistically significant differences by gender, country, or age group.

Fewer men than women reported being perpetrators of physical violence
(OR, 0.76; 95\% CI, 0.65-0.88; $p<0.001$ ), and prevalence fell sharply with age compared to the 18-21 age group $(p<0.001)$ (Figure 2). There were no significant differences in the prevalence of physical violence between the three participating countries.

In general, among the perpetrators, the type of violence that varied the most across countries and between genders was sexual coercion. Compared to Barbados, there was a higher prevalence of sexual coercion in Ja- maica (OR, 2.20; 95\% CI, 1.70-2.86; $p<$ 0.001 ) and Trinidad and Tobago (OR, 1.31 ; 95\% CI, 1.05-1.64; $p=0.02$ ). Jamaica reported the highest levels of sexual coercion, but in all three countries, women consistently reported significantly higher levels of sexual coercion than men, both as perpetrators and as victims. The risk of sexual coercion also fell with age $(p<0.001)$.

\section{Severe forms of physical violence among partners}

The data were further broken down to examine gender, age, and country variations among those who were exposed to or perpetrated the more serious forms of physical violence within partnerships. The more serious forms of violence were defined as those that resulted in physical harm, and/or the use of a weapon, and/or that necessitated a visit to a health facility. The analysis is presented in Table 7. It may be noted that the drop-off in IPV by age was more dramatic in this subgroup of violent events, and Jamaica seemed to report fewer violent events than either Barbados or Trinidad and Tobago. In addition, and of particular importance, there was no significant difference between men and women in the number of reported violent events either on or by survey respondents.

TABLE 7. The effect of age, gender, and country of survey respondent on severe forms of physical violence ${ }^{a}$ within intimate relationships in Barbados, Jamaica, and Trinidad and Tobago, 2003-2004

\begin{tabular}{|c|c|c|c|c|c|c|}
\hline & \multicolumn{3}{|c|}{ On survey respondent } & \multicolumn{3}{|c|}{ By survey respondent } \\
\hline & \multicolumn{2}{|c|}{$\mathrm{OR}^{\mathrm{b}}\left(95 \% \mathrm{Cl}^{\mathrm{c}}\right)$} & \multirow[t]{2}{*}{$P^{d}$} & \multicolumn{2}{|c|}{ OR $(95 \% \mathrm{Cl})$} & \multirow[t]{2}{*}{$P^{\mathrm{d}}$} \\
\hline Age (versus $15-18$ age & & & & & & \\
\hline $19-22$ & 0.55 & $(0.45-0.67)$ & $<0.001$ & 0.52 & $(0.43-0.64)$ & $<0.001$ \\
\hline $23-26$ & 0.35 & $(0.28-0.44)$ & $<0.001$ & 0.32 & $(0.26-0.41)$ & $<0.001$ \\
\hline $27-30$ & 0.30 & $(0.23-0.39)$ & $<0.001$ & 0.24 & $(0.18-0.33)$ & $<0.001$ \\
\hline \multicolumn{7}{|c|}{ Country (versus Barbados) } \\
\hline Jamaica & 0.61 & $(0.47-0.78)$ & $<0.001$ & 0.67 & $(0.51-0.88)$ & 0.004 \\
\hline Trinidad and Tobago & 0.96 & $(0.77-1.21)$ & 0.75 & 0.93 & $(0.72-1.20)$ & 0.57 \\
\hline \multicolumn{7}{|l|}{ Gender (versus men) } \\
\hline women & 1.07 & $(0.89-1.29)$ & 0.72 & 1.04 & $(0.88-1.23)$ & 0.66 \\
\hline
\end{tabular}

a Those that resulted in physical harm, and/or the use of a weapon, and/or that necessitated a visit to a health facility.

${ }^{b} \mathrm{OR}=$ odds ratio.

${ }^{c} \mathrm{Cl}=$ confidence interval.

d Differences in the prevalence of severe physical violence were assessed using logistic regression adjusting for age (in 4-year age groups), gender, and country (Barbados, Jamaica, Trinidad and Tobago) of survey respondent, simultaneously, with statistical significance assumed at $p \leq 0.05$. 


\section{DISCUSSION}

The data reported in this article indicate a greater vulnerability of Caribbean men (versus women) to physical violence by strangers, and-with the possible exception of Trinidad and Tobago-a greater vulnerability of Caribbean women (versus men) to sexual coercion. However, when all types of violence from strangers and acquaintances, and within intimate partnerships, are examined, it is difficult not to be struck by the magnitude of the problem for both men and women in all of the countries studied. Among male victims, the figures reported for exposure to physical violence alone ranged from 54 to $61 \%$; inclusion of other types of violence increases this figure to $63-73 \%$. Among females, the respective proportions are $53-58 \%$ and $65-83 \%$, respectively. These figures fall in-and even surpass-the upper end of the 10-69\% range reported in surveys worldwide $(1,17,48)$.

The level of violence is greatest in Jamaica. However, the limited variations across the three countries-despite their economic and social differencesare noteworthy, as well as the fact that when differences do occur, they do not necessarily fall in the expected direction. Jamaica, for example, reported higher levels of physical violence outside of relationships, compared to both Barbados and Trinidad and Tobago, but there were no significant betweencountry differences for physical violence within relationships; all fell within an incidence range of 40-54\%with Jamaica at the lower end. Even when the more severe forms of violence between partners are considered, Jamaica-with the lowest economic development indices, and the highest levels of violence overall-seemed to report fewer events than either Barbados or Trinidad and Tobago.

According to this study, the arena for most violence and injury is indeed the partner or intimate relationship setting; this is similar to the findings from other studies (1). However, it is useful to note the large discrepancy between exposure to IPV within the context of a partnership, and that in- volving strangers or acquaintances. The proportion reporting physical assault by a stranger or acquaintance does not exceed $20 \%$, whereas the proportion reporting assault by an intimate partner is never less than $40 \%$. This, together with the finding that while IPV increases with age for strangers and acquaintances, it decreases with age for partners, could suggest that there may be limited overlap between the two types of experiences and perpetrators.

Social ecologists have asserted the existence of a "spatial concentration of violence," and violent and resourcedeprived communities are generally expected to encourage domestic partner violence $(1,28,49,50)$. The results presented here, however, raise an important question: Given the apparently widespread occurrence of IPV and aggression, how useful are explanations and identification of risk factors based on the view that violence and aggression is something perpetrated by a minority of criminals, sociopaths, deviants, and delinquents? ${ }^{7}$ An important hypothesis of problembehavior theory is that myriad behavioral problems stem from an underlying deviance syndrome, that is, they are interconnected manifestations of an underlying disposition toward deviance (51). The data from this study, however, along with that from the study by Bogart et al. (52), seem to contradict this hypothesis. Although some concur with the idea of the existence of a single risk factor in emerging adulthood that has a basis in adolescent risk, the evidence does not support this generalized risk factor as the cause of the variance in the individual risk indicators.

There is some evidence that living in a violent neighborhood does not necessarily produce violent children, and not everyone who is identified as "at risk" becomes involved in violence (53). The study reported on in this article, for example, suggests that co-

\footnotetext{
7 The author's question is elaborated further in the summary of a workshop held in June 2007 by the National Academies of Sciences Institute of Medicine (Washington, D.C., USA) (54).
}

occurrence of different types of violence or "clustering" is limited, and one type of violence is not necessarily a predictor of another. This supports Saunders' 1992 finding that those considered generally violent are only responsible for $20 \%$ of domestic violence (55). It may thus be deduced that only a limited relationship (if any) exists between the causes of violence within partnerships and the causes of violence outside partnerships. Evidence that the causes are different would have implications for decision-making regarding optimal intervention strategies for different types of violent behaviors. In any case, the limited cooccurrence of the different types of violence analyzed in this study was an unexpected finding and is therefore a potential area for further investigation. It also suggests a need for better differentiation of the various pathways to sociopathic versus socioculturally tolerated behaviors.

In fact, speculation on whether or not there are spatial concentrations of sociopaths and delinquents or if such concentrations would be more likely to occur among the poor and resourcedeprived may be irrelevant. As suggested in a qualitative study of IPV and aggression conducted in Barbados (21), and by the author of this study (see footnote 7), it may be more helpful to recognize the existence of a universal culture of adversarial relationships, in a global environment permissive of the expression of violent solutions. The data from this study provide quantitative support for that possibility, and for some of the other conclusions that emerged from the qualitative study in Barbados. Among male respondents, when conflicts arose, a "win" versus negotiation and compromise tended to be the sought-after outcome; domestic quarrels were a "challenge" by the partner to be overcome, and a "war" to be won. Among both male and female respondents, emotional and psychological abuse-with its potentially long-lasting impactswas feared to a considerably greater extent than was physical violence, with the latter considered more bearable because it had a clear beginning 
and end (21). In contexts in which violent and aggressive behaviors may be seen as a fairly normal and even valued means of social intercourse and negotiation, it seems logical to question the usefulness of conceptual frameworks that attribute social pathologies and "deviant" behaviors to various social problems and/or dysfunctional scenarios such as social exclusion and poverty and/or single, female-headed households. As noted by Tilley and Brackley (56), for many cases in which violence and aggression may be seen as "normal" and/or "deserved," the causal suspects or triggers are not the same.

Some have theorized that the root causes of violence lie in the legacy of slavery (19-20). Given the high reported levels of violence found in societies without this kind of history (1), however, alternative explanations may need to be identified. In any event, it seems necessary to accurately identify the current factors that "justify" violent solutions. More attention needs to be given to identification of the dynamics, mores, and values in the wider cultural and social systems that may condone and even encourage violent behaviors.

Finklehor et al. asserted that "most studies on individual types of victimization have failed to obtain complete victimization profiles" (57: 8). The same could be said about studies of the perpetrators. This deficiency has allowed for over-exaggeration, understatement, and a complete lack of understanding of the impacts of particular types of victimization. For example, in societies where violence may be highly tolerated, the impacts-singly or cumulatively-may be quite different than in those less tolerant of violence. It thus becomes critical to pose the following questions: In environments that tolerate high levels of violence, what is it that protects some individuals from suffering from or perpetrating IPV and aggression in intimate as well as nonintimate violent situations?

The other finding that is of particular significance is the general absence of significant gender differentials in exposure to and perpetration of physical violence among partners. The quantita- tive data and analysis from this study support suggestions from earlier studies $(21,44)$ about the possible significance of male battery in the three countries as well as conclusions from those studies that recognize the narrowness or narrowing of the "gender gap" $(58,59)$. The results of this study also support conclusions from qualitative studies conducted in the Caribbean, which also indicate the existence of male battery $(22,60)$. In addition, this study's quantitative data on femaleinitiated violence support the view that a culture of adversarial intimate relationships may be well entrenched (21).

Although Strauss and Gelles (61-62) recognized the reality of male battery some time ago, there appears to have been some reluctance (perhaps as a consequence of ideological and cultural blinkers) to discuss or analyze this apparent syndrome $(58,32)$. In fact, male battery may not be a recent phenomenon: there is evidence that throughout history men have suffered violence at the hands of their wives and partners (63-65). However, very little is known about whether the risk factors for male battery are any different from those for female battery; as Kernsmith (66) has observed, few studies have examined the "why" and "how" of female-perpetrated violence. Some studies now seek to determine if the higher incidence of female violence currently being reported is either retaliatory in nature, or the result of more accurate measurements and/or reporting, or if it is, in fact, the result of women acting as aggressors/initiators or perpetrators (67-70). This is an area that requires a great deal more information, exploration, and analysis.

In the current study, the level of reported sexual coercion of men by females is high, unexpected, and perhaps even counter-intuitive. In addition, in two of the three countries (Barbados and Jamaica), the proportion of females reporting themselves as a perpetrator of sexual coercion was higher than that of males reporting themselves as a victim (ranging from $47-68 \%$ and from $40-57 \%$, respectively). This discrepancy may be due to men's unwillingness to report battery and coercion by females, resulting in an understatement of male victimization levels, or to females overexaggerating their actual activities.

With or without an exact correlation to the levels reported by self-described female perpetrators, the levels of sexual coercion by women being reported by males are high (53 and 57\% in Trinidad and Tobago and Jamaica, respectively). This could be related to male perceptions of being under threat or siege found in a qualitative study of males in at least one Caribbean country (21). In most Caribbean societies-including the three examined in this studyavailable aggregate national data (13, 45-47) show that females significantly outperform males at all levels of the educational system, and that while females may still be disadvantaged in terms of economic status and employment levels, they now experience greater social and economical mobility than males. As males increasingly fall further behind women and/or feel threatened or unable to perform their expected roles, reports of IPV perpetrated against them by women could stem from their perceptions and fears rather than actual reality. In either case, the figures for this type of IPV are remarkably large and therefore likely describe a significant reality requiring more in-depth analysis.

The data presented do not support that of other studies that suggest male/ female rates of self-reporting the perpetration of physical IPV is only similar for low levels of physical violence (6, 30). Reports from survey respondents show that in terms of perpetration between partners, there was no gender differential at higher levels of violence. Gender reporting may be skewed by the fact that females are likely to suffer greater injury than men in any confrontation (30); however, the capacity to inflict injury or violence should probably not be confused with the intent to be aggressively violent. This is an issue that requires further exploration. In any case, the likelihood that the "gender gap" may now be almost nonexistent reinforces the view that structural and psychosocial supports need to be better identified. Developing effective interventions and solutions requires a com- 
prehensive understanding of the IPV phenomenon. It is therefore critical to determine if explanations of and intervention strategies for IPV should be based on/customized according to the gender of the perpetrator.

\section{Limitations}

This study has several limitations, including the possibility of gender reporting bias, a syndrome that calls for further research. Reports on domestic violence indicate the existence of this type of bias, in which women report a greater number of events (e.g., psycho- logical aggression, assault and injury) as both perpetrators and victims. Nevertheless, it may be argued that while the possible significance of a reporting bias needs to be carefully examined and addressed, the proportion of physical violence reportedly perpetrated by women is so high that the associated prevalence rates and conclusions would not be significantly affected. Another study limitation stems from the possibility that some of the reported sexual battery of males could pertain to menon-men activities. As this study did not ask about homosexual activities, it was not possible to separate violence between male partners from that occur- ring among heterosexual partners. Given the homophobic character of these societies, however, homosexuality and its related activities would most likely be very under-reported (71), making it difficult to address this limitation in future studies.

Acknowledgments. This study was carried out under the auspices of the Sir Arthur Lewis Institute of Social and Economic Studies (SALISES) at The University of the West Indies in Kingston, Jamaica. It was funded by The Wellcome Trust (London, UK), to whom the authors express their gratitude.

\section{REFERENCES}

1. Krug EG, Mercy J, Dahlberg L, Zwi A, Lozano $\mathrm{R}$, editors. World report on violence and health. Geneva: World Health Organization; 2002.

2. Winett LB. Constructing violence as a public health problem. Public Health Rep. 1998; 113(6):498-507.

3. Buvinic M, Morrison A. Violence as an obstacle to development. Washington: Inter-American Development Bank; 1999. IADB Technical Note No. 4.

4. Caribbean Community Secretariat (CAREC). Report of the Caribbean Commission on health and development. Kingston (Jamaica): Ian Randle Publishers; 2006.

5. Pan American Health Organization. Health conditions in the Americas. 1998 ed., Vol. 1. Washington: PAHO; 2002.

6. Centers for Disease Control and Prevention (US), National Center for Injury Prevention and Control. Economic cost of injury. Source of payment. In: Cost of injury in the United States: a report to Congress [document on the Internet]. Atlanta: CDC; 2007 [updated 2007 June 22; cited 2007 August 5]. Available from: http://www.cdc.gov/ncipc/pub-res/cost_ of_injury/ch2-3.pdf.

7. Heise LL, Ellsberg M, Gottmoeller E. Ending violence against women. Baltimore: Johns Hopkins University School of Public Health, Centre for Communications Programs; 1999. Population Reports. Series L, No. 11.

8. Centers for Disease Control and Prevention (US), National Center for Injury Prevention and Control. Understanding intimate partner violence fact sheet [document on the Internet]. Atlanta: CDC; 2007 [updated 2007 June 22; cited 2007 August 5]. Available from: http://www.cdc.gov/ncipc/dvp/IPV/ default.htm.

9. Campbell JC, Soeken K. Forced sex and intimate partner violence: effects on women's risk and women's health. Violence Against Wom. 1999;5(9):1017-35.

10. Centers for Disease Control and Prevention (US), National Center for Injury Prevention and Control. CDC injury fact book [document on the Internet]. Atlanta: CDC; 2007 [updated 2007 June 22; cited 2007 August 7]. Available from: www.cdc.gov/ncipc/fact_book/fact book. htm.

11. Prothrow-Stith D, Spivak H, Hasman AJ. The violence prevention project: a public health approach. Sci Technol Hum Val. 1987;12(3-4): 67-9.

12. West Virginia Injury Prevention Coalition; West Virginia University Center for Rural Emergency Medicine. Introduction. The burden of injury. In: Fatal injury in West Virginia [document on the Internet]. Charleston (WV): WVIPC/WVU-CREM; 2002 [cited 2007 August 8]. Available from: www.wvdhr.org/ $\mathrm{bph} /$ oehp/injury/report/introduction.pdf and www.wvdhr.org/bph/oehp/injury/report/ burden.pdf.

13. Planning Institute of Jamaica. Economic and Social Survey Jamaica (ESS). Kingston: PIJ; 1995-2001.

14. CAREC.org [homepage on the Internet]. Port of Spain (Trinidad and Tobago): Pan American Health Organization; c2004 [cited 2004 March 28]. Available from: www.carec.org.

15. Royal Saint Vincent and the Grenadines Police Force. Royal Police Force statistics. Kingstown: RSVGPF; 2003.

16. United Nations Population Fund. The state of world population 2000. Lives together, worlds apart. Men and women in a time of change [document on the Internet]. New York: UNFPA; 2000 [cited 2003 August 23]. Available from: www.unfpa.org/swp/2000/english.

17. Fritz GK. Domestic violence hurts children as well as adults. Brown Univ Child Adolesc Behav Lett. 2000;16(7):8.
18. Danns G, Parsad B. Domestic violence and marital relationships in the Caribbean: a Guyana case study. Georgetown: University of Guyana, Women's Study Unit; 1989.

19. Gopaul R, Morgan P, Reddock R. Women, family and family violence in the Caribbean: the historical and contemporary experience with special reference to Trinidad and Tobago. Kingston and St. Augustine: Caribbean Community Secretariat; University of the West Indies, Centre for Gender and Development Studies; 1996.

20. Clarke R. Violence against women in the Caribbean. State and non-state responses. New York: United Nations Development Fund for Women; 1998.

21. Le Franc ER, Rock L. Domestic violence in Barbados: changing interpersonal relationship dynamics. Christ Church, Barbados: United Nations Development Fund for Women; 2003.

22. Centers for Disease Control and Prevention (US), National Center for Injury Prevention and Control. Youth violence: fact sheet [document on the Internet]. Atlanta: CDC; 2007 [updated 2007 April 19; cited 2007 August 5]. Available from: http://www.cdc.gov/ncipc/ factsheets/yvfacts.htm.

23. Halpern C, Oslak S, Young M, Martin S, Kupper LL. Partner violence among adolescents in opposite-sex romantic relationships: findings from the national longitudinal study of adolescent health. Am J Public Health. 2001; 91(10):1679-85.

24. Bailey W, Branche C, Le Franc ER. Family and the quality of gender relations in the Caribbean. Caribbean Dialogue: A Policy Bulletin of Caribbean Affairs. 1998;4 Spec no. 1-2.

25. McHugh MC, Livingston NA, Ford A. A postmodern approach to women's use of violence: developing multiple and complex conceptualizations. Psychol Women Q. 2005;29(3): 323-36. 
26. Hall D, Lynch M. Violence begins at home: domestic strife has lifelong effects on children. Brit Med J. 1998;316(7144):1551-60.

27. Quisumbing A, Haddad L, Peña C. Are women over-represented among the poor? An analysis of poverty in ten developing countries. Washington: International Food Policy Research Institute; 1995. IFPRI Discussion Paper No. 115.

28. Riner M, Saywell RM. Development of the Social Ecology Model of Adolescent Interpersonal Violence Prevention (SEMAIVP) [research papers]. J School Health. 2002;72(2): $65-70$.

29. Diez-Roux AV. Bringing context back into epidemiology. Am J Public Health. 1998;88(2): 216-22.

30. Gelles RJ. Through a sociological lens: social structure and family violence. In: Gelles RJ, Loseke DR, editors. Current controversies on family violence. Newbury Park (CA): Sage; 1993. p. 31-46.

31. Archer J. Sex differences in aggression between heterosexual partners: a meta-analytic review. 2000. Psychol Bull. 126(5):651-80.

32. Graham-Kevan N, Archer J. Investigating three explanations of women's relationship aggression. Psychol Women Quart. 2005; 29(3):270-7.

33. Ellsberg M, Heise L, Peña R, Agurto S, Winkvist A. Researching domestic violence against women: methodological and ethical considerations. Stud Fam Plann. 2001;32(1): $1-16$.

34. Blum WR, Halcón L, Pate E, CampbellForrester S, Venema V. Adolescent health in the Caribbean: risk and protective factors. Am J Public Health. 2003;93(3):456-60.

35. Raj A, Silverman JG, Amaro H. Abused women report greater male partner risk and gender-based risk for HIV: findings from a community-based study with Hispanic women. AIDS Care. 2004;16(4):519-29.

36. Flake DF, Forste R. Fighting families: family characteristics associated with domestic violence in five Latin American countries. J Fam Violence. 2006;21(1):19-29.

37. Rosenthal BS, Wilson WC. Adolescents' psychological response to the experience of community interpersonal violence: a crossnational and a cross-cultural comparison. Adolescence. 2006;41(163):417-33.

38. Blum WR, Ireland M. Reducing risk, increasing protective factors: findings from the Caribbean Youth Health Survey. J Adolescent Health. 2004;35(6):493-500.

39. Samms-Vaughan M, Jackson M, Ashley D, Lambert M. A comprehensive analysis of Jamaican children's exposure to violence at 11-12 years. Washington: Pan American Health Organization; 2005.

40. Meeks-Gardner JM, Powell CA, GranthamMcGregor SM. Determinants of aggressive and prosocial behaviour among Jamaican schoolboys. West Indian Med J. 2007;56(1): 34-41.

41. Straus MA, Hamby SL, Boney-McCoy S, Sugarman DB. The Revised Conflict Tactics Scales (CTS2): development and preliminary psy- chometric data. J Fam Issues. 1996;17(3): 283-316.

42. Rains, C. Conflict Tactics Scales. Fast Track Project technical report [document on the Internet]. Durham (NC): Fast Track; 2002 [cited 2004 January 10]. Available from: http:// www.fasttrackproject.org/techrept/c/cft/.

43. Canadian Centre for Justice Statistics, Statistics Canada. Violence Against Women Survey 1993. Ottawa: CCJS, Statistics Canada; 1993.

44. Le Franc ER, Rock L. The commonality of gender-based violence. J East Caribb Stud. 2002;26(1):74-82.

45. Barbados Statistical Service. 2000 population and housing census. Barbados Census 2000. Vol. 1. Bridgetown: BSS; 2002.

46. Trinidad and Tobago. Central Statistical Office. Population census of Trinidad and Tobago 2000. Port of Spain: Ministry of Planning and Development, Government Printery; 2000.

47. Statistical Institute of Jamaica. Jamaica labour force surveys. Kingston: STATIN; 2004-7.

48. Baleta A. Studies reveal the extent of domestic violence in South Africa. Lancet. 1999;354 (9178):580.

49. Birchard K. Ireland tackles rising tide of domestic violence. Lancet. 1999;354 (9196):2146.

50. Malik S, Sorenson SB, Aneshensel CS. Community and dating violence among adolescents: perpetration and victimisation. J Adolesc Health. 1997;21(5):291-302.

51. Jessor R, Jessor SL. Problem behaviour and psychosocial development: a longitudinal study of youth. New York: Academic Press; 1977.

52. Bogart LM, Collins RL, Ellickson PL, Klein DJ. Adolescent predictors of generalized health risk in young adulthood: a 10-year longitudinal assessment. J Drug Issues. 2006;36(3): 571-95.

53. Stewart EA, Simons RL, Conger RD. Assessing neighbourhood and social psychological influences on childhood violence in an African-American sample. Criminology. 2002; 40(4):801-30.

54. National Academies of Sciences (US), Institute of Medicine, Board of Global Health. Gender-based violence in the Caribbean. In: Violence prevention in low- and middleincome countries: finding a place on the global agenda. Workshop summary. Washington: National Academies Press; 2008. p. 85. Available from: http://books.nap.edu/open book.php?record_id=12016\&page $=85$.

55. Saunders DG. A typology of men who batter: three types derived from cluster analysis. Am Orthopsychiatry. 1992;62(2):264-75.

56. Tilley DS, Brackley M. Men who batter intimate partners: a grounded theory study of the development of male violence in intimate partner relationships. Issues Ment Health Nurs. 2005;26(3):281-297.

57. Finkelhor D, Ormrod RK, Turner HA. Polyvictimization: a neglected component in child victimization. Child Abuse Neglect. 2007; 31(1):7-26.

58. Frieze IH. Female violence against intimate partners: an introduction. Psychol Women Quart. 2005;29(3):229-37.
59. Garbarino J. See Jane hit: why girls are growing more violent and what we can do about it. New York: Penguin Press; 2006.

60. Le Franc ER, Riley-Hunte P, Wharton K. Violence against children: an evaluation of the protective environment. Participant Assessment Methodology: a case study in Dominica. Bridgetown (Barbados): United Nations Children's Fund; 2006.

61. Straus M. Measuring intra-family conflict and violence: the Conflict Tactics (CT) Scales. J Marriage Fam. 1979;41(1):75-88.

62. Straus M, Gelles R. Physical violence in American families: risk factors and adaptations to violence in 8,145 families. New Brunswick (NJ): Transaction Publishers; 1990.

63. Graham-Kevan N. The re-emergence of male victims [introduction to special issue]. Int J Men's Health. 2007;6 Spec no. 1:3-6.

64. Richardson DS. The myth of female passivity: thirty years of revelations about female aggression. Psychol Women Quart. 2005;29(3): 238-47.

65. Benenson JF, Dolenszky E, Sinclair N. Children's and adolescents' expectations of aggressive responses to provocation: females predict more hostile reactions in compatible dyadic relationships. Soc Dev. 2006;15(1): 65-81.

66. Kernsmith P. Gender differences in the impact of family of origin violence on perpetrators of domestic violence. J Fam Violence. 2006;21(2):163-71.

67. Katz J, Kuffel SW, Coblentz A. Are there gender differences in sustaining dating violence? An examination of frequency, severity, and relationship satisfaction. J Fam Violence. 2002; 17(3):247-71.

68. Steffensmeier D, Schwartz J, Zhong H, Ackerman J. An assessment or recent trends in girls violence using diverse longitudinal sources: is the gender gap closing? Criminology. 2005; 43(2):355-406.

69. White JW, Smith PH, Koss MP, Figueredo AJ. Intimate partner aggression: what have we learned? [comment]. Psychol Bull. 2000;126(5): 690-6.

70. Graves KN, Sechrist SM, White JW, Paradise MJ. Intimate partner violence perpetrated by college women within the context of a history of victimization. Psychol Women Quart. 2005; 29(3):278-89.

71. Wyatt G, Le Franc ER, Tucker MB, Bain B, Mitchell-Kernan B, Simeon D. Sexual decision-making among Jamaicans. Final report 1990-1994. Washington: Family Health International; 1994.

Manuscript received on 2 November 2007. Revised version accepted for publication on 29 April 2008. 
RESUMEN Objetivos. Se informa la prevalencia de dos formas de violencia interpersonal (VIP) —la sexual y la física- y de un tipo de agresión — la psicológica - en tres países del Caribe de bajo a mediano ingresos. Se analiza la VIP entre adolescentes y adultos jóvenes, ya sea como víctimas o agresores.

Violencia interpersonal en tres países del Caribe: Barbados, Jamaica y Trinidad y Tobago

Métodos. En este estudio basado en la población se comparan las experiencias de personas de 15 a 30 años de países con diferentes niveles de desarrollo socioeconómico. Se utilizó la escala revisada de tácticas de conflicto (CTS2) y otros instrumentos de análisis conductual para evaluar el nivel y las características de la VIP.

Resultados. De las 3401 personas que respondieron, 70,9\% informó haber sido víctima de alguna forma de violencia, más frecuentemente ejercida por sus parejas $(62,8 \%)$. Las mujeres informaron con mayor frecuencia haber sido víctimas de violencia sexual, y esta fue más frecuente en Jamaica. Se encontraron diferencias significativas entre los países en cuanto a la violencia física y la agresión psicológica, que se hicieron notables al estratificar por el tipo de agresor.

Conclusiones. Los muy elevados niveles informados de VIP indican un alto grado de tolerancia entre las víctimas e indican que se puede estar arraigando una cultura de violencia y de relaciones íntimas basadas en el enfrentamiento. Estos resultados confirman que la ocurrencia simultánea de la violencia interpersonal en general y la violencia de pareja puede ser limitada y que una forma no necesariamente es un factor de predicción de la otra. En las parejas no se observaron diferencias en la victimización según el género y más mujeres que hombres se declararon agresoras en esta forma de VIP.

Palabras clave Violencia sexual, violencia doméstica, agresión, conducta del adolescente, adultos, Barbados, Jamaica, Trinidad y Tobago. 